\title{
Elevated levels of circulating IL-7 and IL-15 in patients with early stage prostate cancer
}

\author{
Chantal Mengus ${ }^{*}$, Clémentine Le Magnen¹, Emanuele Trella', Kawa Yousef ${ }^{1}$, Lukas Bubendorf ${ }^{2}$, \\ Maurizio Provenzano ${ }^{1,3}$, Alexander Bachmann ${ }^{4}$, Michael Heberer ${ }^{1}$, Giulio C Spagnoli and Stephen Wyler ${ }^{4}$
}

\begin{abstract}
Background: Chronic inflammation has been suggested to favour prostate cancer (PCA) development. Interleukins (IL) represent essential inflammation mediators. IL-2, IL-7, IL-15 and IL-21, sharing a common receptor $\gamma$ chain (c- $\gamma$ ), control T lymphocyte homeostasis and proliferation and play major roles in regulating cancer-immune system interactions. We evaluated local IL-2, IL-7, IL-15 and IL-21 gene expression in prostate tissues from patients with early stage PCA or benign prostatic hyperplasia (BPH). As control, we used IL-6 gene, encoding an IL involved in PCA progression. IL-6, IL-7 and IL-15 titres were also measured in patients' sera.
\end{abstract}

Methods: Eighty patients with BPH and 79 with early (1 to 2c) stage PCA were enrolled. Gene expression in prostate tissues was analyzed by quantitative real-time PCR (qRT-PCR). Serum IL concentrations and acute phase protein titres were evaluated by ELISA. Mann-Whitney, Wilcoxon and $\chi^{2}$ tests were used to compare IL gene expression and serum titers in the two groups of patients. Receiver operating characteristic (ROC) curves were constructed to evaluate the possibility to distinguish sera from different groups of patients based on IL titers.

Results: IL-2 and IL-21 gene expression was comparably detectable, with low frequency and at low extents, in PCA and BPH tissues. In contrast, IL-6, IL-7 and IL-15 genes were expressed more frequently $(p<0.0001, p=0.0047$ and $p=0.0085$, respectively) and to significantly higher extents ( $p=0.0051, p=0.0310$ and $p=0.0205$, respectively) in early stage PCA than in BPH tissues. Corresponding proteins could be detected to significantly higher amounts in sera from patients with localized PCA, than in those from patients with BPH $(p=0.0153, p=0.0174$ and $p=$ 0.0064 , respectively). Analysis of ROC curves indicates that IL-7 ( $p=0.0039)$, but not IL-6 ( $p=0.2938)$ or IL-15 ( $p=$ 0.1804) titres were able to distinguish sera from patients with malignancy from those from patients with benign disease. Serum titres of $C$ reactive (CRP), high mobility group B1 (HMGB1) and serum amyloid A (SAA) acute phase proteins were similar in both groups of patients.

Conclusions: Expression IL-7 and IL-15 genes in prostate tissues and corresponding serum titres are significantly increased in patients with early stage PCA as compared with patients with BPH.

\section{Background}

Prostate cancer (PCA) is the second leading cause of cancer-related death in men with a death rate reaching 26.7\% for 2001-2005 in United States[1]. Chronic inflammation has been suggested to play a major role in prostate oncogenesis[2]. Furthermore, local and systemic immunosuppression have also been reported in patients bearing PCA[3-6]. The clarification of molecular mechanisms underlying these phenomena might provide

\footnotetext{
* Correspondence: cmengus@uhbs.ch

'ICFS, Departments of Surgery and Biomedicine, Basel University Hospital, Basel, Switzerland

Full list of author information is available at the end of the article
}

novel insights into PCA induction and progression, of potentially high clinical relevance.

Cytokines represent key mediators of inflammation and play pivotal roles in the interaction between immune system and cancer. A number of them have been suggested to be associated with advanced stage PCA[7]. IL-4 and, in particular, IL-6 have been shown to exert antiapoptotic effects on PCA cells, whereas proangiogenic effects of IL-8 have been demonstrated [7].

A group of lymphokines including, among others, IL2, IL-7, IL-15 and IL-21 share a receptor $\gamma$-chain[8]. Common receptor $\gamma$-chain $(c-\gamma)$ cytokines regulate

\section{Biomed Central}


lymphocyte development [9-12] and support CD4+ and CD8 + T cell homeostatic proliferation and functions $[13,14]$. IL-2, IL-7, IL-15 and IL-21 are of particular interest in cancer immunotherapy[15]. Importantly, IL-2 is FDA approved for the treatment of melanoma and renal cell carcinoma, whereas IL-7 has been used with promising results in phase I/II trials in clinical oncology $[16,17]$. IL-15 has not yet been used in clinical trials. However, experimental models and "in vitro" evidence suggest that it may represent a cancer treatment with high potential clinical relevance[18-20]. Finally, IL-21 has been shown in murine models to prevent $\mathrm{T}$ lymphocyte exhaustion induced by chronic stimulation[21-23]. In phase I/II clinical trials, IL-21 has also shown reproducible antitumor effects[24,25].

Notably, however, elevated IL-7 serum levels have been detected in Hodgkin disease and in ovarian cancers [26-29]. Furthermore, IL-7 has been shown to be produced by breast and colorectal cancer cells[30,31]. IL-15 has also been shown to be produced by colon cancer cells and specific gene expression has been shown to be associated with distant metastases [32]. Moreover, elevated IL-15 serum levels were detected in multiple myeloma[33].

Little is known about IL-2, IL-7, IL-15 and IL-21 gene expression and protein secretion in patients bearing PCA or BPH. Indeed, IL-2 gene expression and IL-15 protein have been detected in BPH tissues[34,35]. Furthermore, IL-7 gene has been found to be expressed in PCA tissues[36,37] and the corresponding protein has been detected in patients' sera. However, no comparative analysis in patients with $\mathrm{BPH}$ and PCA has been performed so far and no data are currently available for IL-21 expression in PCA and BPH.

In order to evaluate the potential role of these IL in early phases of prostate oncogenesis, in this study we have evaluated the expression of specific genes in prostatic tissues from patients bearing either localized pT12c PCA or BPH and we have measured the titres of circulating proteins in their sera.

Our results indicate that in prostatic tissues from patients bearing early stage PCA, the expression of IL-7 and IL-15 genes is significantly enhanced, as compared to $\mathrm{BPH}$, while no significant differences could be observed in IL-2 or IL-21 gene expression. Accordingly, titres of circulating IL- 7 and IL-15 are increased in patients with localized PCA, as compared to patients with $\mathrm{BPH}$. Most interestingly, IL-7 titres might help to discriminate sera from patients with $\mathrm{PCA}$ or $\mathrm{BPH}$.

\section{Patients and methods \\ Patients}

We investigated a consecutive series of 159 specimens from men diagnosed for $\mathrm{BPH}$ or $\mathrm{PCA}$ at the
Department of Urology of the University Hospital of Basel (Switzerland) from 2007 to 2010. Patients with $\mathrm{BPH}$ underwent conventional transurethral resection (TUR-P), while patients with PCA underwent either palliative TUR-P or endoscopic extraperitoneal radical prostatectomy (EERP). Relevant clinical data were collected by reviewing patients' files.

Written informed consent was obtained from patients in accordance with the requirements of the Ethical Committee of Basel (EKBB, Ref.Nr. EK: 176/07).

\section{Quantification of gene expression in prostatic tissues by quantitative Real-Time PCR}

Prostatic tissues were screened for the presence of tumors by an experienced pathologist (L. Bubendorf). Total RNA was extracted by using RNeasy ${ }^{\circledR}$ MiniKit (Qiagen, Basel, Switzerland), deoxyribonuclease I (Invitrogen, Carlsbad, California) treated and reverse transcribed by using M-MLV Reverse Transcriptase (Invitrogen, Carlsbad, California). Quantitative RT-PCR was performed using the TaqMan ${ }^{\circledR}$ Universal PCR Master Mix (Applied Biosystems, Forster City, CA), and the following primers and probes:

GAPDH[38]

Fwd ATGGGGAAGGTGAAGGTCG

Rev TAAAAGCAGCCCTGGTGACC

Probe FAM-CGCCCAATACGACCAAATCCGTTGAC-TAMRA

IL-2[39]

Fwd AACTCACCAGGATGCTCACATTTA

Rev TCCCTGGGTCTTAAGTGAAAGTTT

Probe FAM-TTTTACATGCCCAAGAAGGCCACAGAACT-TAMRA

IL-6[40]

Fwd CAGCCCTGAGAAAGGAGACATG

Rev GGTTCAGGTTGTTTTCTGCCA

Probe FAM-AGTAACATGTGTGAAAGCAGCAAAGAGGCAC-TAMRA

IL-21, IL-7 and IL-15 primers and probes were provided by Assays-on-Demand, Gene Expression Products (Applied Biosystems, Forster City, CA).

Specific gene expression was quantified by using the $2^{-}$ $\Delta \Delta \mathrm{C}_{\mathrm{T}}$ method[41]. Normalization of gene expression was performed using GAPDH as reference gene.

\section{ELISA assays}

Commercial ELISA kits for IL-6, IL-7 and IL-15 were obtained from Pharmingen (San Diego, CA). Detection limit was $1 \mathrm{pg} / \mathrm{ml}$ for all assays. HMGB1 ELISA kit was obtained from Shino-Test Corporation (Kanagawa, Japan). SAA and CRP ELISA kits were obtained from USB (Swampscott, MA) and Roche Diagnostics Cobas ${ }^{\circledR}$ (Mannheim, Germany), respectively. Detection limits were $1 \mathrm{ng} / \mathrm{ml}, 0.6 \mathrm{ng} / \mathrm{ml}$, and $0.6 \mu \mathrm{g} / \mathrm{ml}$, for HMGB1, 
SAA and CRP, respectively. All assays were performed in accordance to the instructions from the producers.

\section{Statistical Analysis}

Mann-Whitney tests were used to compare mean expression of cytokine genes and cytokine serum titers for independent samples while Wilcoxon test was used for paired samples. When $n \geq 30$, Student's T-Tests were used to compare means. Frequencies of specific gene expression in two groups were assessed by $\chi^{2}$ tests. Differences with $\mathrm{p}<0.05$ were considered significant. Receiver operating characteristic (ROC) curves were created to verify whether cytokine titers could be used to distinguish patients with PCA from patients with $\mathrm{BPH}$ [27].

\section{Results}

\section{Clinico-pathological profiles of the patients}

A group including 79 patients (average age \pm SEM = $64.3 \pm 0.8)$ undergoing surgical treatment for localized stage 1-2 PCA and a group of 80 patients (average age \pm SEM $=68.1 \pm 0.9$ ) undergoing surgical treatment for $\mathrm{BPH}$ were enrolled in the study. Of the 79 PCA patients, 2 (2.6\%) were diagnosed with stage pT1, 2 (2.6\%) with stage pT1a, $1(1.3 \%)$ with stage pT1b, $3(3.8 \%)$ with stage pT2, 13 (16.4\%) with stage pT2a, 4 (5\%) with stage pT2b, 54 (68.3\%) with stage pT2c.

Average serum Prostate Specific Antigen (PSA) \pm SEM in PCA patients was $8.26 \pm 1.46 \mathrm{ng} / \mathrm{ml}(\mathrm{n}=74)$ and average Gleason score \pm SEM was $6.63 \pm 0.10(\mathrm{n}=78)$. Average serum PSA value \pm SEM in BPH patients was $5.49 \pm 0.87 \mathrm{ng} / \mathrm{ml}(\mathrm{n}=63)$.

\section{Expression of $\mathrm{c}-\gamma$ cytokines genes in prostatic tissues}

In the initial phase of our study, we quantitatively analyzed IL-2, IL-7, IL-15 and IL-21 gene expression in a series of tissue samples from localized PCA and $\mathrm{BPH}$. As shown in figure 1, IL-2 gene expression was detectable in 20/32 (62.5\%) and in 37/49 (75.5\%) BPH and PCA specimens, respectively $(\mathrm{p}=0.2099)$. Under a quantitative view point, comparably low levels of expression could be observed in BPH and PCA tissues ( $\mathrm{p}=$ $0.1721)$

In contrast, IL-7 gene expression was significantly more frequently observed in PCA than in BPH specimens [29/ $34(85.3 \%)$ and $51 / 51(100 \%) \mathrm{BPH}$ and PCA, respectively $(\mathrm{p}=0.0047)]$. IL-15 gene was also expressed more frequently in PCA than in BPH samples [16/31 (51.6\%) and $39 / 49$ (79.6\%) BPH and PCA specimens, respectively $(\mathrm{p}=$ 0.0085)]. Notably, under a quantitative point of view, IL7 and IL-15 gene expression was also significantly increased in tissues from patients bearing early stage PCA as compared to those from patients with $\mathrm{BPH}(\mathrm{p}=$ 0.0310 and $\mathrm{p}=0.0205$, respectively, figure 1 ).

IL-21 gene expression was relatively rarely detectable in prostatic tissues from patients bearing $\mathrm{BPH}$ or stage pT1-2c PCA [3/26 (11.5\%) and 4/47 (8.5\%) BPH and PCA tissues, respectively $(\mathrm{p}=0.6739)]$. Furthermore, the

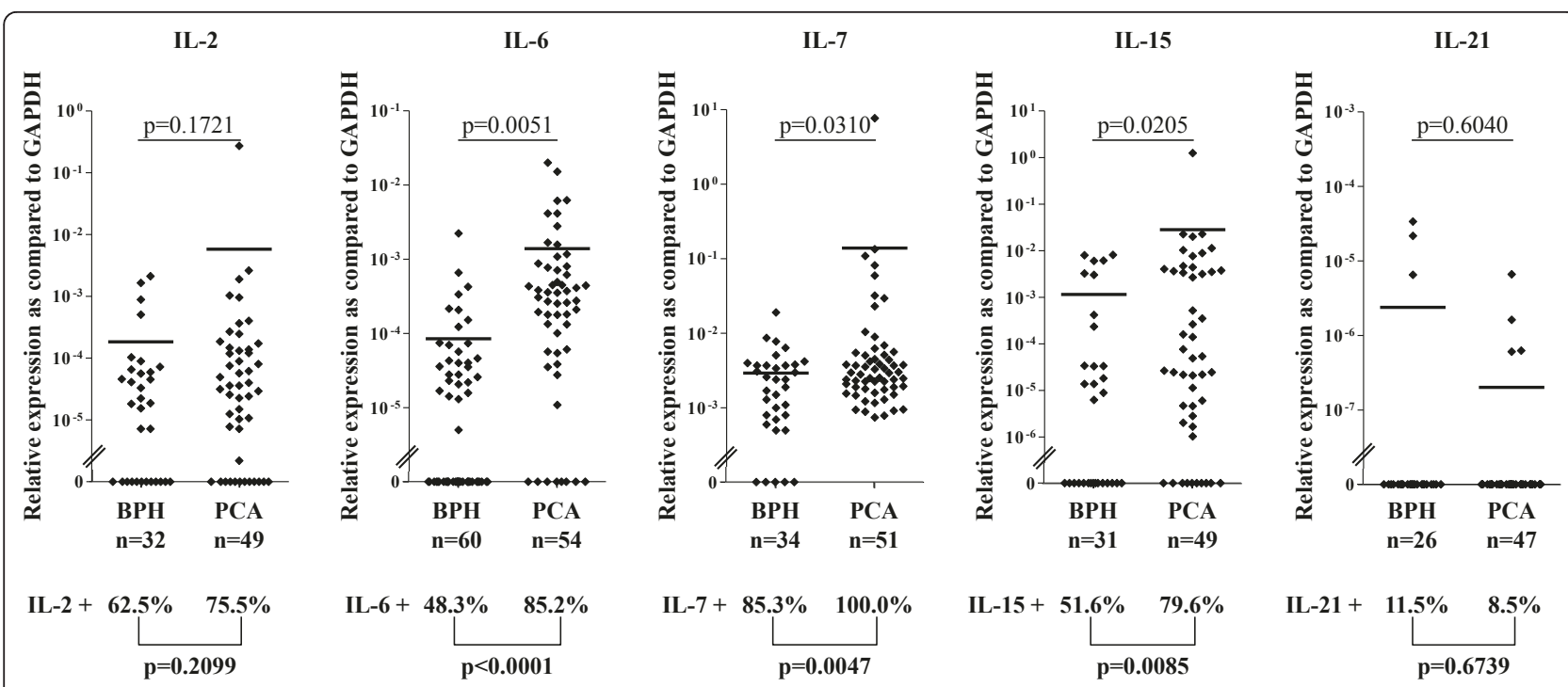

Figure 1 Expression of IL genes in early stage PCA and BPH tissues. Total cellular RNA was extracted from BPH and PCA tissues, DNAse treated, reverse transcribed and analyzed by quantitative real-time PCR for IL-2 (BPH: $n=32, P C A: n=49), I L-7$ (BPH: $n=34, P C A: n=51), I L-15$ (BPH: $n=31, P C A: n=49), ~ I L-6(B P H: n=60, P C A: n=54)$ and IL-21 (BPH: $n=26, P C A: n=47)$ specific gene expression. Data are expressed as ratio to GAPDH gene expression. Mean values $(\mathbf{-})$ are indicated for each group. Digits in individual panels indicate percentages of samples displaying gene expression levels exceeding detection limits (bold, bottom of the panel) and statistical significance of differential extent of specific gene expression in BPH or PCA specimens (top of the panel). 
average level of expression did not significantly differ in the two groups $(\mathrm{p}=0.6040$, figure 1$)$.

IL-6 is known to be a mediator of PCA morbidity, and may act as a cell growth factor and protect cancer cells from death[42]. Therefore, we used the expression of this gene as control of the integrity of our assays. Indeed, IL-6 gene expression was detected in 29/60 (48.3\%) and in 46/54 (85.2\%) BPH and early stage PCA specimens, respectively $(\mathrm{p}<0.0001)$. Under a quantitative point of view, IL-6 gene expression was also significantly increased in tissues from patients bearing PCA as compared to BPH $(\mathrm{p}=0.0051)$, thus confirming our previous findings[43].

Taken together these data indicate that although genes encoding the c- $\gamma$ cytokines under investigation may be expressed in BPH tissues, IL-7 and IL-15 genes are expressed to a significantly higher extent in localized PCA.

IL-6 gene was previously found to be expressed by prostate cancer cells [44]. To address the issue of the nature of the cell types possibly expressing other cytokine genes in PCA tissues, we evaluated IL-2, IL-7, IL15 and IL-21 gene expression in PC3, DU145 and LNCaP established PCA cell lines. Interestingly, we found that all cell lines expressed IL-15 gene, whereas IL-6 and IL-7 genes were only expressed in PC3 and DU145 cells (figure 2). In contrast, IL-2 and IL-21 genes were not expressed by any of the cell lines under investigation.

\section{Detection of $c-\gamma$ cytokines in sera from patients with early stage PCA}

High IL-6 serum titres have been observed in advanced PCA [42]. Furthermore, increased IL-7 serum titres have been reported in PCA[37], as compared to non age matched healthy donors, but no comparison with sera from patients with $\mathrm{BPH}$ was attempted, nor were patients with early stage PCA specifically studied. In order to verify, at the systemic level our findings from $\mathrm{BPH}$ and localized PCA tissues, we comparatively evaluated circulating titres of IL-6, IL-7 and IL-15 in preoperative sera from patients with prostatic diseases.

IL-6 was highly significantly increased even in sera from patients with $\mathrm{pT} 1-2 \mathrm{c}$ stage PCA, as compared to sera from patients with BPH (average IL-6 concentration $\pm \mathrm{SEM}=57.34 \pm 12.12$ vs. $27.46 \pm 2.62 \mathrm{pg} / \mathrm{ml}, \mathrm{p}=$ 0.0153 , figure 3A.1.). Most interestingly, serum levels of IL-7 and IL-15 were also significantly higher in patients with localized PCA as compared to patients with $\mathrm{BPH}$ (average IL-7 concentration \pm SEM $=32.69 \pm 9.73$ vs. $5.87 \pm 1.17 \mathrm{pg} / \mathrm{ml}, \mathrm{p}=0.0174$ and average IL-15 concentration \pm SEM $208.07 \pm 48.50$ vs. $50.51 \pm 14.34 \mathrm{pg} /$ $\mathrm{ml}, \mathrm{p}=0.0064$, figure 3A.1.). Remarkably, a highly significant correlation was observed between IL-7 and IL15 levels in sera from patients with either early stage PCA $(\mathrm{p}<0.0001, \mathrm{R}=0.6631, \mathrm{n}=50)$ or $\mathrm{BPH}(\mathrm{p}<$ $0.0001, \mathrm{R}=0.6019, \mathrm{n}=40$ ) (Figure 3, panels A.2. and A.3.).

Notably, cytokine serum titres did not significantly correlate with the specific expression of the corresponding gene in autologous prostate tissues.

\section{IL-7 serum titres distinguish patients with BPH or PCA}

ROC curves were constructed to verify whether serum IL titres could help distinguishing patients with localized PCA from patients with BPH (Figure 3B). Interestingly, although specific serum titres were significantly higher in patients with PCA, as compared with patients with $\mathrm{BPH}$, areas under curve (AUC) were small for IL-6 (AUC: 0.5547, 95\%CI: 0.4515-0.6579) and IL-15 (AUC: 0.5825, 95\%CI: 0.4647-0.7003). Therefore, these cytokine titres were not helpful in identifying patients with early stage






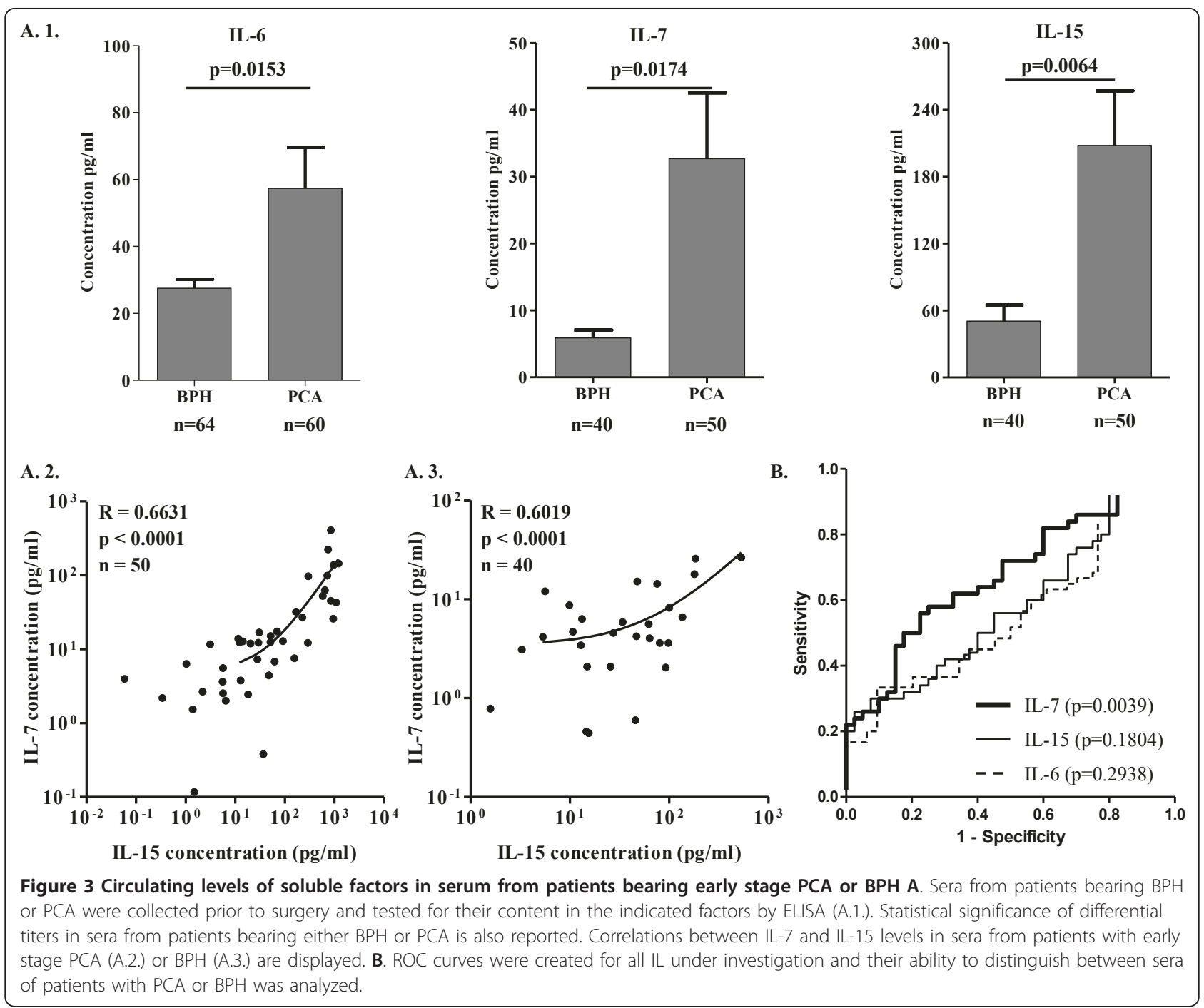

malignancies ( $\mathrm{p}=0.2938$ and $\mathrm{p}=0.1804$, respectively). In contrast, analysis of the ROC curve for IL-7 (AUC: 0.6775, 95\%CI: 0.5676-0.7874 $\mathrm{p}=0.0039$ ) indicated that specific IL titres were effectively distinguishing patients with early stage PCA from patients with $\mathrm{BPH}$.

Table 1 Acute phase protein concentrations in sera from patients with early stage PCA and BPH

\begin{tabular}{llccc}
\hline & & $\begin{array}{c}\text { CRP } \\
(\mu \mathrm{g} / \mathrm{ml})\end{array}$ & $\begin{array}{c}\text { SAA } \\
(\boldsymbol{\mu} \mathbf{g} / \mathrm{ml})\end{array}$ & $\begin{array}{c}\text { HMGB1 } \\
(\mathbf{n g} / \mathbf{m l})\end{array}$ \\
\hline Early stage PCA & Average & 7.47 & 2.81 & 52.77 \\
& SEM & 1.92 & 0.31 & 12.48 \\
& $\mathbf{n}$ & 66 & 18 & 18 \\
\hline BPH & Average & 5.70 & 2.71 & 49.11 \\
& SEM & 1.16 & 0.29 & 15.13 \\
& $\mathbf{n}$ & 66 & 19 & 19 \\
\hline $\mathbf{p}$ & & 0.4370 & 0.7728 & 0.7497 \\
\hline
\end{tabular}

Detection of acute phase proteins in sera from patients with early stage PCA

Serum biomarkers of systemic inflammation $C$ reactive protein (CRP) and serum amyloid A (SAA), have been found to be associated with PCA [45-47]. Furthermore, HMGB1 gene has been suggested to be overexpressed in prostate PCA [48]. The corresponding gene product is a prominent member of a group of mediators released by damaged cells, collectively known as damage associated molecular patterns (DAMP)[49]. These factors might be responsible for the activation of the innate immune system, potentially resulting in cytokine gene expression and secretion[50].

We did not observe significant differences between sera from patients with early stage PCA and those from patients with $\mathrm{BPH}$ regarding CRP, SAA or HMGB1 levels (Table 1: average CRP concentration \pm SEM 7.47 $\pm 1.92 \mu \mathrm{g} / \mathrm{ml}$ vs. $5.70 \pm 1.16 \mu \mathrm{g} / \mathrm{ml}, \mathrm{p}=0.4370$; average 
SAA concentration \pm SEM $2.81 \pm 0.31$ vs. $2.71 \pm 0.29$ $\mu \mathrm{g} / \mathrm{ml}, \mathrm{p}=0.7728$; average HMGB1 concentration \pm SEM $52.77 \pm 12.48$ vs. $49.11 \pm 15.13 \mathrm{ng} / \mathrm{ml}, \mathrm{p}=0.7497$ ). Notably, no significant correlation could be observed between IL-6, IL-7 or IL-15 serum levels and acute phase protein titres. Similarly, no correlation with PSA levels or Gleason score was detectable.

\section{Discussion}

A large body of literature based on histopathological, epidemiological and molecular pathology data suggests that chronic inflammation might play an important role in prostate oncogenesis [2]. IL represent essential mediators of inflammation and titres of a number of them have been shown to be increased in patients bearing PCA[7]. Most of these studies, however, have addressed IL detection in patients with advanced stage cancers. In these conditions, high tumor burdens and mechanisms inherent with metastatic spread, e,g, osteolysis, might be involved in the induction of IL production. Furthermore, sterile inflammation primed by intratumoral ischemia and associated necrosis could also promote IL release [51]. Therefore, data from patients with advanced tumors are unlikely to provide useful information on the role eventually played by inflammation or immunosuppression in prostate oncogenesis. In order to gain insights into events occurring in early stages of prostate cancerogenesis, in this study we evaluated IL gene expression and protein production at local and systemic levels, respectively, in localized PCA, as compared with $\mathrm{BPH}$.

Our data clearly indicate that the expression of a number of genes encoding pro-inflammatory and homeostatic IL, including IL-6, IL-7 and IL-15 is detectable more frequently and to a higher extent, in early stage PCA as compared to BPH tissues. Notably, the genes encoding these IL were also found to be expressed to different levels by established PCA cell lines.

To investigate the possibly systemic nature of the proinflammatory state detectable in PCA[37,52], we measured IL titres in sera from patients with BPH or early stage PCA. We report here for the first time that IL-7 and IL-15 serum levels are significantly higher in patients with localized PCA than in patients with BPH. IL-6 titres were also significantly higher in patients with PCA than in patients with BPH despite the early stage of their disease [53].

IL-6 is known to be produced by multiple cell types, including activated macrophages, smooth muscle cells and PCA cells [53]. Instead, IL-7 is produced by multiple stromal cell types and epithelial cells from different districts including thymus and gut[10]. Most recently IL-7 production has been detected in normal, but not in transformed prostate epithelial cells[36]. IL-15 is typically produced by activated antigen presenting cells of the myeloid lineage, including monocytes, macrophages and dendritic cells. However, IL-15 gene has also been found to be expressed by a multiplicity of other cell types, including stromal and epithelial cells[9]. Importantly, epithelial $\mathrm{BPH}$ cells have been shown to express IL-15[34]. In our patients, IL serum titres were not significantly correlated with specific gene expression in the autologous prostate tissues, thereby suggesting that cells other than tumor cells might be at least in part responsible for IL production. Thus, while we here show that IL-6, IL-7 and IL-15 genes are expressed in established PCA cell lines, future studies are warranted to clarify the cellular sources of these IL within the prostate and systemically.

The nature of the mechanisms promoting IL-6, IL-7 and IL-15 gene expression and protein production in PCA is also unclear. Different microorganisms, including virus and bacteria $[54,55]$ have been suspected to contribute to oncogenesis in the prostate. Indeed, their presence could result in chronic inflammation. Alternatively, it has been suggested that direct damage of epithelial cells might be caused by toxic compounds contained in urines or by dietary factors[2]. Cell death might, in turn, result in the activation of the innate immune system by DAMPs [49]. Soluble factors produced by DAMP-triggered innate immune system cells, including IL-6, have repeatedly been suggested to promote prostate cancerogenesis[2]. However, here we show that at least circulating levels of HMGB1, SAA and CRP acute phase proteins are similar in patients with $\mathrm{BPH}$ or localized, early stage PCA.

Analysis of ROC curves indicates that IL-7, but neither IL-6 nor IL-15 titres do distinguish sera from patients with PCA from sera from patients with $\mathrm{BPH}$. These findings might set the stage for larger studies also addressing the clinical relevance of IL-7 serum titres in the monitoring of PCA response to treatment and recurrences.

On the other hand, our data raise the issue of potential functional consequences of $\mathrm{c}-\gamma$ cytokine gene expression and secretion in PCA. Preliminary experiments indicate that none of the IL under investigation enhances the proliferation of cells from established PCA cell lines (data not shown). However, studies performed in breast cancer [56] indicate that IL-7 promotes the production of proangiogenic factors by tumor cells and proliferation of endothelial cells. IL-15 has also been shown to stimulate angiogenesis "in vivo" [57]. Furthermore, although IL-7 and IL-15 are known to promote survival and functional maturation of $\mathrm{T}$ cells, they have also been demonstrated to induce the expression of PD-1 "exhaustion" marker in these cells[58]. Indeed, PCA tissues have been shown to be infiltrated by $\mathrm{T}$ cells largely expressing $\mathrm{PD}-1$, and, less 
frequently, PD-L1 and PD-L2[59,60]. These data are consistent with previous reports on the phenotypic characteristics of circulating and tissue infiltrating lymphocytes in chronic viral infections[61-64]. In this context, it is remarkable that we found that the expression of the IL21 gene, that is of the gene encoding the cytokine preventing PD-1 mediated T cell exhaustion[21-23] is rarely detectable in PCA.

\section{Conclusions}

Our work indicates that even in early stages of PCA development, genes encoding IL of pro-inflammatory significance are over-expressed in malignant tissues, as compared to BPH specimens, Importantly, corresponding proteins are detectable to higher levels in sera from patients with localized PCA as compared to patients with $\mathrm{BPH}$, and, in particular, IL-7 titres might represent an additional marker of potential clinical relevance.

\section{List of abbreviations}

AUC: area under curve; BPH: benign prostatic hyperplasia; $\mathrm{Cl}$ : confidence interval; CRP: C-reactive protein; c- $\gamma$ : common receptor $\gamma$ chain; DAMP: damage associated molecular patterns; EERP: endoscopic extraperitoneal radical prostatectomy; ELISA: enzyme-linked immunosorbent assay; GAPDH: glyceraldehyde-3-phosphate dehydrogenase; HMGB1: high mobility group B1; IL: interleukin; mAb: monoclonal antibody; PCA: prostate cancer; PD-1: programmed death receptor-1; PD-L1 and -L2: programmed death ligand-1 and ligand-2; PSA: prostate specific antigen; qRT-PCR: quantitative real-time polymerase chain reaction; $R O C$ : receiver operating characteristic; SAA: serum amyloid A; TUR-P: transurethral resection.

\section{Acknowledgements and Funding}

This work was partially supported by unrestricted grants from Astra Zeneca, the Freiwillige Akademische Gesellschaft Basel, the Lichtenstein Stiftung Basel, Novartis Research Foundation (formerly Ciba-Geigy Jubilee

Foundation), Swiss National Fund for Scientific Research and the Department of Surgery of the University Hospital Basel.

\section{Author details}

IICFS, Departments of Surgery and Biomedicine, Basel University Hospital, Basel, Switzerland. ${ }^{2}$ Institute of Pathology, Basel University Hospital, Basel, Switzerland. ${ }^{3}$ Oncology Research Unit, Division of Urology and Division of Surgical Research, Zurich University Hospital, Zurich, Switzerland.

${ }^{4}$ Department of Urology, Basel University Hospital, Basel, Switzerland.

\section{Authors' contributions}

All authors read and approved the final manuscript. CM, CLM, ET and KY participated in the design, acquisition and analysis of data. GCS and MP and SW conceived the study; GCS, MH and AB provided funding support and revised the manuscript critically for important intellectual content. LB made substantial contributions to the analysis and interpretation of data.

\section{Competing interests}

The authors declare that they have no competing interests.

Received: 17 June 2011 Accepted: 26 September 2011 Published: 26 September 2011

\section{References}

1. Jemal A, Thun MJ, Ries LA, Howe HL, Weir HK, Center MM, Ward E, Wu XC, Eheman $C$, Anderson $R$, et al: Annual report to the nation on the status of cancer, 1975-2005, featuring trends in lung cancer, tobacco use, and tobacco control. J Natl Cancer Inst 2008, 100:1672-1694.
2. De Marzo AM, Platz EA, Sutcliffe $S, X u$ J, Gronberg H, Drake CG, Nakai Y, Isaacs WB, Nelson WG: Inflammation in prostate carcinogenesis. Nat Rev Cancer 2007, 7:256-269.

3. Ebelt K, Babaryka G, Figel AM, Pohla H, Buchner A, Stief CG, Eisenmenger W, Kirchner T, Schendel DJ, Noessner E: Dominance of CD4+ lymphocytic infiltrates with disturbed effector cell characteristics in the tumor microenvironment of prostate carcinoma. Prostate 2008, 68:1-10.

4. Miller AM, Lundberg K, Ozenci V, Banham AH, Hellstrom M, Egevad L, Pisa P: CD4+CD25high T cells are enriched in the tumor and peripheral blood of prostate cancer patients. J Immunol 2006, 177:7398-7405.

5. Miller AM, Pisa P: Tumor escape mechanisms in prostate cancer. Cancer Immunol Immunother 2007, 56:81-87.

6. Yokokawa J, Cereda V, Remondo C, Gulley JL, Arlen PM, Schlom J, Tsang KY Enhanced functionality of CD4+CD25(high)FoxP3+ regulatory T cells in the peripheral blood of patients with prostate cancer. Clin Cancer Res 2008, 14:1032-1040.

7. Culig Z: Cytokine disbalance in common human cancers. Biochim Biophys Acta 2011, 1813:308-314.

8. He YW, Malek TR: The structure and function of gamma c-dependent cytokines and receptors: regulation of $\mathrm{T}$ lymphocyte development and homeostasis. Crit Rev Immunol 1998, 18:503-524.

9. Fehniger TA, Caligiuri MA: Interleukin 15: biology and relevance to human disease. Blood 2001, 97:14-32

10. Fry TJ, Mackall CL: Interleukin-7: from bench to clinic. Blood 2002, 99:3892-3904.

11. Leonard WJ, Spolski R: Interleukin-21: a modulator of lymphoid proliferation, apoptosis and differentiation. Nat Rev Immunol 2005, 5:688-698

12. Schluns KS, Lefrancois L: Cytokine control of memory T-cell development and survival. Nat Rev Immunol 2003, 3:269-279.

13. Moroz A, Eppolito C, Li Q, Tao J, Clegg CH, Shrikant PA: IL-21 enhances and sustains CD8+ $T$ cell responses to achieve durable tumor immunity: comparative evaluation of IL-2, IL-15, and IL-21. J Immunol 2004, 173:900-909.

14. von Holzen U, Adamina M, Bolli M, Weber WP, Zajac P, Groeper C, Reschner A, Feder C, Schumacher R, Marti W, et al: Selective responsiveness to common gamma chain cytokines in peripheral bloodderived cytotoxic T lymphocytes induced by Melan-A/MART-1(27-35) targeted active specific immunotherapy. Int J Cancer 2005, 115:248-255.

15. Fewkes NM, Mackall CL: Novel gamma-chain cytokines as candidate immune modulators in immune therapies for cancer. Cancer J 2010, 16:392-398.

16. Rosenberg SA, Sportes C, Ahmadzadeh M, Fry TJ, Ngo LT, Schwarz SL, Stetler-Stevenson M, Morton KE, Mavroukakis SA, Morre M, et al: IL-7 administration to humans leads to expansion of CD8+ and CD4+ cells but a relative decrease of CD4+ T-regulatory cells. J Immunother 2006, 29:313-319.

17. Sportes C, Babb RR, Krumlauf MC, Hakim FT, Steinberg SM, Chow CK, Brown MR, Fleisher TA, Noel P, Maric I, et al: Phase I study of recombinant human interleukin-7 administration in subjects with refractory malignancy. Clin Cancer Res 2010, 16:727-735.

18. Melchionda F, Fry TJ, Milliron MJ, McKirdy MA, Tagaya Y, Mackall CL: Adjuvant IL-7 or IL-15 overcomes immunodominance and improves survival of the CD8+ memory cell pool. J Clin Invest 2005, 115:1177-1187.

19. Oh S, Berzofsky JA, Burke DS, Waldmann TA, Perera LP: Coadministration of HIV vaccine vectors with vaccinia viruses expressing IL-15 but not IL-2 induces long-lasting cellular immunity. Proc Natl Acad Sci USA 2003, 100:3392-3397.

20. Rosenthal R, Groeper C, Bracci L, Adamina M, Feder-Mengus C, Zajac P, lezzi G, Bolli M, Weber WP, Frey DM, et al: Differential responsiveness to IL-2, IL-7, and IL-15 common receptor gamma chain cytokines by antigen-specific peripheral blood naive or memory cytotoxic CD8+ T cells from healthy donors and melanoma patients. J Immunother 2009, 32:252-261.

21. Elsaesser H, Sauer K, Brooks DG: IL-21 is required to control chronic viral infection. Science 2009, 324:1569-1572.

22. Frohlich A, Kisielow J, Schmitz I, Freigang S, Shamshiev AT, Weber J, Marsland BJ, Oxenius A, Kopf M: IL-21R on T cells is critical for sustained functionality and control of chronic viral infection. Science 2009, 324:1576-1580. 
23. Yi JS, Du M, Zajac AJ: A vital role for interleukin-21 in the control of a chronic viral infection. Science 2009, 324:1572-1576

24. Davis ID, Brady B, Kefford RF, Millward M, Cebon J, Skrumsager BK, Mouritzen U, Hansen LT, Skak K, Lundsgaard D, et al: Clinical and biological efficacy of recombinant human interleukin-21 in patients with stage IV malignant melanoma without prior treatment: a phase Ila trial. Clin Cancer Res 2009, 15:2123-2129.

25. Thompson JA, Curti BD, Redman BG, Bhatia S, Weber JS, Agarwala SS, Sievers EL, Hughes SD, DeVries TA, Hausman DF: Phase I study of recombinant interleukin-21 in patients with metastatic melanoma and renal cell carcinoma. J Clin Oncol 2008, 26:2034-2039.

26. Chopra V, Dinh TV, Hannigan EV: Angiogenin, interleukins, and growthfactor levels in serum of patients with ovarian cancer: correlation with angiogenesis. Cancer J Sci Am 1996, 2:279-285.

27. Lambeck AJ, Crijns AP, Leffers N, Sluiter WJ, ten Hoor KA, Braid M, van der Zee AG, Daemen T, Nijman HW, Kast WM: Serum cytokine profiling as a diagnostic and prognostic tool in ovarian cancer: a potential role for interleukin 7. Clin Cancer Res 2007, 13:2385-2391.

28. Trumper L, Jung W, Dahl G, Diehl V, Gause A, Pfreundschuh M: Interleukin7, interleukin-8, soluble TNF receptor, and p53 protein levels are elevated in the serum of patients with Hodgkin's disease. Ann Oncol 1994, 5(Suppl 1):93-96.

29. Xie X, Ye D, Chen H, Lu W, Cheng B, Zhong H: Interleukin-7 and suppression of local peritoneal immunity in ovarian carcinoma. Int $J$ Gynaecol Obstet 2004, 85:151-158.

30. Al-Rawi MA, Rmali K, Watkins G, Mansel RE, Jiang WG: Aberrant expression of interleukin-7 (IL-7) and its signalling complex in human breast cancer. Eur J Cancer 2004, 40:494-502.

31. Maeurer MJ, Walter W, Martin D, Zitvogel L, Elder E, Storkus W, Lotze MT: Interleukin-7 (IL-7) in colorectal cancer: IL-7 is produced by tissues from colorectal cancer and promotes preferential expansion of tumour infiltrating lymphocytes. Scand J Immunol 1997, 45:182-192.

32. Kuniyasu H, Ohmori H, Sasaki T, Sasahira T, Yoshida K, Kitadai Y, Fidler IJ: Production of interleukin 15 by human colon cancer cells is associated with induction of mucosal hyperplasia, angiogenesis, and metastasis. Clin Cancer Res 2003, 9:4802-4810.

33. Pappa C, Miyakis S, Tsirakis G, Sfiridaki A, Alegakis A, Kafousi M, Stathopoulos EN, Alexandrakis MG: Serum levels of interleukin-15 and interleukin-10 and their correlation with proliferating cell nuclear antigen in multiple myeloma. Cytokine 2007, 37:171-175.

34. Handisurya A, Steiner GE, Stix U, Ecker RC, Pfaffeneder-Mantai S, Langer D, Kramer G, Memaran-Dadgar N, Marberger M: Differential expression of interleukin-15, a pro-inflammatory cytokine and T-cell growth factor, and its receptor in human prostate. Prostate 2001, 49:251-262.

35. Kramer G, Steiner GE, Handisurya A, Stix U, Haitel A, Knerer B, Gessl A, Lee C, Marberger M: Increased expression of lymphocyte-derived cytokines in benign hyperplastic prostate tissue, identification of the producing cell types, and effect of differentially expressed cytokines on stromal cell proliferation. Prostate 2002, 52:43-58.

36. Di CE, D'Antuono T, Pompa P, Giuliani R, Rosini S, Stuppia L, Musiani P, Sorrentino C: The lack of epithelial interleukin-7 and BAFF/BLyS gene expression in prostate cancer as a possible mechanism of tumor escape from immunosurveillance. Clin Cancer Res 2009, 15:2979-2987.

37. Roato I, D'Amelio P, Gorassini E, Grimaldi A, Bonello L, Fiori C, Delsedime L, Tizzani $A$, De LA, Isaia $G$, et al: Osteoclasts are active in bone forming metastases of prostate cancer patients. PLOS ONE 2008, 3:e3627.

38. Martin I, Jakob M, Schafer D, Dick W, Spagnoli G, Heberer M: Quantitative analysis of gene expression in human articular cartilage from normal and osteoarthritic joints. Osteoarthritis Cartilage 2001, 9:112-118.

39. Giulietti A, Overbergh L, Valckx D, Decallonne B, Bouillon R, Mathieu C: An overview of real-time quantitative PCR: applications to quantify cytokine gene expression. Methods 2001, 25:386-401.

40. Hartwig D, Hartel C, Hennig H, Muller-Steinhardt M, Schlenke P, Kluter H: Evidence for de novo synthesis of cytokines and chemokines in platelet concentrates. Vox Sang 2002, 82:182-190.

41. Livak KJ, Schmittgen TD: Analysis of relative gene expression data using real-time quantitative PCR and the 2(-Delta Delta C(T)) Method. Methods 2001, 25:402-408.

42. Twillie DA, Eisenberger MA, Carducci MA, Hseih WS, Kim WY, Simons JW: Interleukin-6: a candidate mediator of human prostate cancer morbidity. Urology 1995, 45:542-549.
43. Feder-Mengus C, Wyler S, Hudolin T, Ruszat R, Bubendorf L, Chiarugi A, Pittelli M, Weber WP, Bachmann A, Gasser TC, et al: High expression of indoleamine 2,3-dioxygenase gene in prostate cancer. Eur J Cancer 2008, 44:2266-2275.

44. Chung TD, Yu JJ, Spiotto MT, Bartkowski M, Simons JW: Characterization of the role of IL-6 in the progression of prostate cancer. Prostate 1999, 38:199-207.

45. Kaneti J, Winikoff $Y$, Zimlichman S, Shainkin-Kestenbaum R: Importance of serum amyloid $A$ (SAA) level in monitoring disease activity and response to therapy in patients with prostate cancer. Urol Res 1984, 12:239-241.

46. Pierce BL, Biggs ML, DeCambre M, Reiner AP, Li C, Fitzpatrick A, Carlson CS, Stanford $J$, Austin MA: C-reactive protein, interleukin-6, and prostate cancer risk in men aged 65 years and older. Cancer Causes Control 2009, 20:1193-1203.

47. Prins RC, Rademacher BL, Mongoue-Tchokote S, Alumkal JJ, Graff JN, Eilers KM, Beer TM: C-reactive protein as an adverse prognostic marker for men with castration-resistant prostate cancer (CRPC): Confirmatory results. Urol Oncol 2010.

48. Ishiguro $H$, Nakaigawa N, Miyoshi $Y$, Fujinami K, Kubota $Y$, Uemura $H$ : Receptor for advanced glycation end products (RAGE) and its ligand, amphoterin are overexpressed and associated with prostate cancer development. Prostate 2005, 64:92-100.

49. Kono $\mathrm{H}$, Rock KL: How dying cells alert the immune system to danger. Nat Rev Immunol 2008, 8:279-289.

50. Chen GY, Nunez G: Sterile inflammation: sensing and reacting to damage. Nat Rev Immunol 2010, 10:826-837.

51. Zitvogel L, Casares N, Pequignot MO, Chaput N, Albert ML, Kroemer G: Immune response against dying tumor cells. Adv Immunol 2004, 84:131-179.

52. Schenk JM, Kristal AR, Neuhouser ML, Tangen CM, White E, Lin DW, Kratz M, Thompson IM: Biomarkers of systemic inflammation and risk of incident, symptomatic benign prostatic hyperplasia: results from the prostate cancer prevention trial. Am J Epidemiol 2010, 171:571-582.

53. Culig Z, Steiner H, Bartsch G, Hobisch A: Interleukin-6 regulation of prostate cancer cell growth. J Cell Biochem 2005, 95:497-505.

54. Das D, Wojno K, Imperiale MJ: BK virus as a cofactor in the etiology of prostate cancer in its early stages. J Virol 2008, 82:2705-2714.

55. Namiki K, Goodison S, Porvasnik S, Allan RW, Iczkowski KA, Urbanek C, Reyes L, Sakamoto N, Rosser CJ: Persistent exposure to Mycoplasma induces malignant transformation of human prostate cells. PLOS ONE 2009, 4:e6872.

56. Al-Rawi MA, Watkins G, Mansel RE, Jiang WG: Interleukin 7 upregulates vascular endothelial growth factor $\mathrm{D}$ in breast cancer cells and induces lymphangiogenesis in vivo. Br J Surg 2005, 92:305-310.

57. Angiolillo AL, Kanegane H, Sgadari C, Reaman GH, Tosato G: Interleukin-15 promotes angiogenesis in vivo. Biochem Biophys Res Commun 1997, 233:231-237.

58. Kinter AL, Godbout EJ, McNally JP, Sereti I, Roby GA, O'Shea MA, Fauci AS: The common gamma-chain cytokines IL-2, IL-7, IL-15, and IL-21 induce the expression of programmed death-1 and its ligands. J Immuno/ 2008 181:6738-6746.

59. Ebelt K, Babaryka G, Frankenberger B, Stief CG, Eisenmenger W, Kirchner T, Schendel DJ, Noessner E: Prostate cancer lesions are surrounded by FOXP3+, PD-1+ and B7-H1+ lymphocyte clusters. Eur J Cancer 2009, 45:1664-1672.

60. Sfanos KS, Bruno TC, Meeker AK, De Marzo AM, Isaacs WB, Drake CG: Human prostate-infiltrating CD8+ T lymphocytes are oligoclonal and PD1+. Prostate 2009, 69:1694-1703.

61. Day CL, Kaufmann DE, Kiepiela P, Brown JA, Moodley ES, Reddy S, Mackey EW, Miller JD, Leslie AJ, DePierres C, et al: PD-1 expression on HIVspecific $T$ cells is associated with T-cell exhaustion and disease progression. Nature 2006, 443:350-354.

62. Franceschini D, Paroli M, Francavilla V, Videtta M, Morrone S, Labbadia G, Cerino A, Mondelli MU, Barnaba V: PD-L1 negatively regulates CD4+CD25 +Foxp3+ Tregs by limiting STAT-5 phosphorylation in patients chronically infected with HCV. J Clin Invest 2009, 119:551-564.

63. Golden-Mason L, Palmer B, Klarquist J, Mengshol JA, Castelblanco N, Rosen HR: Upregulation of PD-1 expression on circulating and intrahepatic hepatitis C virus-specific CD8+ T cells associated with reversible immune dysfunction. J Virol 2007, 81:9249-9258. 
64. Radziewicz H, lbegbu CC, Fernandez ML, Workowski KA, Obideen K, Wehbi $\mathrm{M}$, Hanson $\mathrm{HL}$, Steinberg JP, Masopust D, Wherry EJ, et al: Liverinfiltrating lymphocytes in chronic human hepatitis $C$ virus infection display an exhausted phenotype with high levels of PD-1 and low levels of CD127 expression. J Virol 2007, 81:2545-2553.

doi:10.1186/1479-5876-9-162

Cite this article as: Mengus et al: Elevated levels of circulating IL-7 and IL-15 in patients with early stage prostate cancer. Journal of Translational Medicine 2011 9:162.

Submit your next manuscript to BioMed Central and take full advantage of:

- Convenient online submission

- Thorough peer review

- No space constraints or color figure charges

- Immediate publication on acceptance

- Inclusion in PubMed, CAS, Scopus and Google Scholar

- Research which is freely available for redistribution

Submit your manuscript at www.biomedcentral.com/submit 